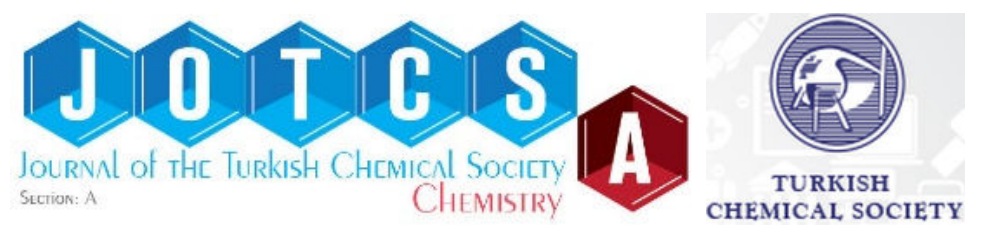

(This article was presented to the 28th National Chemistry Congress and submitted to JOTCSA as a full manuscript)

\title{
Six Coordination Compounds: Mode of Cytotoxic Action and Biological Evaluation
}

\author{
Ali Aydın*1, Şengül Aslan Korkmaz ${ }^{2}$ \\ ${ }^{1}$ Faculty of Art and Science, Department of Molecular Biology and Genetics, Gaziosmanpaşa \\ University, 60240, Tokat, Turkey \\ ${ }^{2}$ Faculty of Engineering, Department of Bioengineering, Tunceli University, 62000, Tunceli, \\ Turkey
}

\begin{abstract}
This study describes the biological and anticancer properties of coordination compounds given in the text. FT-IR spectra, magnetic properties, thermal analyses and crystal structures of six cyanido-complexes derivatives with $\left[\mathrm{M}^{\mathrm{II}}(\mathrm{CN})_{4}\right]^{2-}\left(\mathrm{M}^{\mathrm{II}}=\mathrm{Ni}\right.$ and $\left.\mathrm{Pd}\right)$ and $\left[\mathrm{Co}(\mathrm{CN})_{6}\right]^{3-}$ anions and $N, N$-bishydeten $(N, N$-bis(2-hydroxyethyl)ethylenediamine) as a capping ligand have been reported previously. Here, we have investigated the pharmacological properties of these complexes denoted as $\left[\mathrm{Ni}(\mathrm{N}\right.$-bishydeten $\left.) \mathrm{Ni}(\mathrm{CN})_{4}\right](\boldsymbol{C 1}),\left[\mathrm{Zn}_{2}(\mathrm{~N} \text {-bishydeten })_{2} \mathrm{Ni}(\mathrm{CN})_{4}\right]$ (C2), $\left[\mathrm{Ni}(\mathrm{N}\right.$-bishydeten $\left.) \mathrm{Pd}(\mathrm{CN})_{4}\right] \quad(\boldsymbol{C 3}), \quad\left[\mathrm{Cd}(\mathrm{N} \text {-bishydeten })_{2}\right]\left[\mathrm{Pd}(\mathrm{CN})_{4}\right] \quad(\mathrm{C4}), \quad\left[\mathrm{Ni}_{2}(\mathrm{~N}-\right.$ bishydeten $\left.)_{2} \mathrm{Co}(\mathrm{CN})_{6}\right] .3 \mathrm{H}_{2} \mathrm{O}(\mathbf{C 5})$ and $\mathrm{K}\left[\mathrm{Cd}(\mathrm{N}\right.$-bishydeten $\left.) \mathrm{Co}(\mathrm{CN})_{6}\right] .3 /{ }_{2} \mathrm{H}_{2} \mathrm{O}(\boldsymbol{C} \boldsymbol{6})$, tested for their anti-proliferative activity against human cervical cancer (HeLa), human colon cancer (HT29), rat glioma (C6) and African green monkey kidney (Vero) cell lines. The DNA/BSA binding affinities of these compounds were also elucidated by spectroscopic titrations, displacement experiments, and electrophoresis measurements. Studies on cancerous cells revealed that $\mathbf{C 1}, \mathbf{C 2}, \mathbf{C 4}$ and $\mathbf{C 6}$ have exhibited the significant antitumor activity and inhibited tumor progression during testing cell lines and showed high solubility in the solvent. The results of absorbance and emission spectra data have revealed that the complexes interact with the DNA via groove binding mode of interaction. Overall, these compounds have been found to demonstrate effective antiproliferative activity against the cancer cell lines, indicating that they are a potent candidate for preclinical or clinical studies.
\end{abstract}

Keywords: Coordination compounds, Anticancer activity, Cytotoxic activity, Apoptosis, DNA binding.

Submitted: June 26, 2016. Revised: August 06, 2016. Accepted: September 06, 2016.

Cite this: Aydın A, Aslan Korkmaz Ş. Six Coordination Compounds: Mode of Cytotoxic Action and Biological Evaluation. JOTCSA. 2016;3(3):313-328.

DOI: $10.18596 /$ jotcsa. 37363 .

*Corresponding author. E-mail: aliaydin.bio@gmail.com; ali.aydin4409@gop.edu.tr. Tel: +90356-2521616. Fax: +90-356-2521585. 
Aydın and Aslan Korkmaz, JOTCSA. 2016; 3(3): 313-328.

\section{INTRODUCTION}

Today, cancer is becoming a more life-threatening endemic disease throughout the world and new effective drugs are the main necessity. In the Middle East, cancer ranks the second most common cause of death, following cardiovascular diseases [1]. According to the IARC (International Agency for Research on Cancer), a substantive increase to 19.3 million new cancer cases per year by 2025 were predicted with deaths reaching to the number of 12 million [1]. Developing countries especially suffer from the burden of cancer incidence, morbidity, and mortality [1]. Efforts to reduce the economic burden caused due to the cancer on individuals, families and the healthcare system will increase [1]. Research efforts on the development of novel anticancer agents play an important role in the current treatment process for cancer. These investigations are focused on the goal to find effective drugs without side effects or drug resistance [2-7]. It is known that the metal complexes including copper, gold, germanium, iron, rhenium, rhodium, ruthenium, silver, tin, and titanium have shown anticancer activity. However, none of the compounds have demonstrated sufficient effectiveness to pursue past phase II or past phase III clinical trials except for cis-platin and its certain derivatives such as carboplatin, oxaliplatin, nedaplatin and satraplatin [8]. Only carboplatin is FDA-approved among them. Co ${ }^{\text {II }}$, $\mathrm{Ni}^{\mathrm{II}}, \mathrm{Pd}^{\mathrm{II}}$ or $\mathrm{Zn}^{\mathrm{II}}$ have been used to obtain metal complexes in medicinal studies [9-10]. Nickel plays important roles in the biological functions of various enzymes in systems including electron transport system, together with zinc, sulfur, and iron to form a cluster. Zinc plays ubiquitous biological roles by coordinating amino acid side chains of the specific enzymes in signal transduction and gene expression metabolism. Cobalt is an essential component of vitamin $B_{12}$ that has a vital role in the normal functioning of the nervous system. Palladium is a metal with low toxicity and is like platinum. It is a component of cis-platin, which is an anticancer drug. Nickel, zinc, cobalt and palladium complexes have also shown DNA binding capacity and antiproliferative activity [11-15]. However, metal complex of cyanido and $N$-bishydeten ( $N, N$-bis(2hydroxyethyl)-ethylenediamine) ligands have not been explored in terms of their chemical and chemotherapeutic usage. Our work in this area was concentrated on the use of these ligands to form C1-C6 compounds and test their activities against colon, cervix and glioma cancer. Korkmaz et al. [16-18] have explored the $\mathrm{Ni}^{\mathrm{II}}$ and $\mathrm{Zn}^{\mathrm{II}}$ metal ions with a capping ligand $\mathrm{N}, \mathrm{N}$ bishydeten. The in vitro biological activity of the metal complexes was estimated using the ELISA BrdU cell proliferation assay (CPA) and Lactate Dehydrogenase (LDH) cytotoxicity assay against the cancer cell lines HT29, HeLa, C6, and Vero. The morphology of cells was investigated using phase-contrast microscopy. These complexes have also been studied to determine the extent of their physicochemical properties regarding DNA/BSA binding, and inhibition of restriction in the endonucleases activity features. The interaction of these compounds with DNA/BSA is a significant property in the determination of the mechanisms of compounds because DNA/BSA is a significant chemotherapeutic target for many current anticancer agents. According to the 
Aydın and Aslan Korkmaz, JOTCSA. 2016; 3(3): 313-328.

RESEARCH ARTICLE

present literature, this is the first study investigating the biological activities of the $\mathrm{N}$-bishydeten based complexes.

\section{MATERIALS and METHODS}

\section{Materials}

$\mathrm{NiCl}_{2} .6 \mathrm{H}_{2} \mathrm{O}, \mathrm{ZnCl}_{2}, \mathrm{KCN}, \mathrm{K}_{2}\left[\mathrm{Ni}(\mathrm{CN})_{4}\right], \mathrm{K}_{3}\left[\mathrm{Co}(\mathrm{CN})_{6}\right]$ and $\mathrm{N}, \mathrm{N}$-bis(2-hydroxyethyl)-ethylenediamine ( $N, N$-bishydeten) were obtained commercially (Merck, Germany) and used without further purification.

\section{Synthesis of C1-C6}

In our previous studies, we have reported the synthesis and characteristic properties of $\boldsymbol{C 1 - C 6}$ coordination compounds [16-18]. These compounds were synthesized according to the procedure published before. The procedure is based on brick-and-mortar method. In this method, $\mathrm{Ni}^{\mathrm{II}}$ and $\mathrm{Zn}^{\mathrm{II}}$ metal cations were coordinated with suitable ligand(s) to form the brick and with $\left[\mathrm{M}^{\mathrm{II}}(\mathrm{CN})_{4}\right]^{2-}\left(\mathrm{M}^{\mathrm{II}}=\mathrm{Ni}\right.$ and $\left.\mathrm{Pd}\right)$ and $\left[\mathrm{Co}(\mathrm{CN})_{6}\right]^{3-}$ anions to form the mortar.

\section{Cell culture}

The anticancer potential of these complexes was investigated on cancerous HT29 (ATCC ${ }^{\circledR}$ HTB$38^{\mathrm{TM}}$ ), HeLa (ATCC ${ }^{\circledR} \mathrm{CCL}-2^{\mathrm{TM}}$ ), C6 $\left(\mathrm{ATCC}^{\circledR} \mathrm{CCL}^{-107^{\mathrm{TM}}}\right.$ ) and no tumorigenic Vero cells (ATCC ${ }^{\circledR}$ CCL- $81^{\mathrm{TM}}$ ). The cell lines were cultured in a cell medium (Dulbecco's modified eagle's) enriched with $10 \%(\mathrm{v} / \mathrm{v})$ fetal bovine serum and $2 \%(\mathrm{v} / \mathrm{v})$ Penicillin-Streptomycin $(10,000 \mathrm{U} / \mathrm{mL})$. First, the old medium was removed out of the flask while cells had reached approximately $80 \%$ confluence. Next, cells were taken from the flasks surface using 4-5 mL of trypsin-EDTA solution and then subjected to centrifugation. Following, the cell pellet was suspended with $4 \mathrm{~mL}$ of DMEM working solution and was counted to obtain a final concentration of $5 \times 10^{4} \mathrm{cells} / \mathrm{mL}$, and inoculated into wells $(100 \mu \mathrm{L}$ cells/well).

\section{Cell proliferation assay (CPA)}

A cell suspension containing approximately $5 \times 10^{3}$ cells in $100 \mu \mathrm{L}$ was seeded in the 96 -well culture plates. The complexes and cis-platin were dissolved in sterile DMSO ( $\max 0.5 \%$ of DMSO) at final concentrations of $0.05,0.1,0.2,0.3,0.4,0.5,0.75$, and $1.00 \mathrm{mg} / \mathrm{mL}$. The final volume of the wells was set to $200 \mu \mathrm{L}$ using DMEM working solution. Cells were incubated with tested complexes at $37^{\circ} \mathrm{C}$ with $5 \% \mathrm{CO}_{2}$ for overnight. Cell proliferation assay was analyzed using ELISA BrdU methods as described previously [7]. 


\section{Calculation of IC50 and percent inhibition}

IC50 value is a concentration value at which half of the cells are inhibited in vitro. The half maximal inhibitory concentrations (IC50) of the test and control compounds were calculated using XLfit5 ${ }^{\circledR}$ or Microsoft Excel ${ }^{\circledR}$ spreadsheet and represented in $\mu \mathrm{M}$ at $95 \%$ confidence intervals. The proliferation assay results were expressed as the percent inhibition according to the following formula:

$$
\% \text { inhibition }=\left[1-\left(\frac{\text { Absorbance of treatments }}{\text { Absorbance of DMSO }}\right) \times 100\right]
$$

\section{Cytotoxic activity assay}

The cytotoxicity of the compounds and cis-platin was determined on HeLa, C6, HT29, and Vero cells through a Lactate Dehydrogenase Assay Kit according to the instruction given by manufacturer. Approximately $5 \times 10^{3}$ cells in $100 \mu \mathrm{L}$ were placed in 96-well plate as triplicates and treated with IC50 $(\mu \mathrm{g} / \mathrm{mL})$ concentrations of test compounds at $37^{\circ} \mathrm{C}$ under $5 \% \mathrm{CO}_{2}$ atmosphere for $24 \mathrm{~h}$. LDH activity was obtained at $492-630 \mathrm{~nm}$ absorbance wavelength using a microplate reader.

\section{Cell imaging}

Cells were plated in 96-well plate at a density of 5000 cells per well and allowed $24 \mathrm{~h}$ incubation. IC50 values of the test compounds were administered and morphology changes of the cells were screened via phase contrast microscopy every $6 \mathrm{~h}$ for $24 \mathrm{~h}$. Images of control and test compound-treated cells were photographed at the end of the process using a digital camera attached on inverted microscope.

\section{DNA/BSA binding and gel electrophoresis studies}

The binding constants $(K b)$ and the interaction of the compounds with Calf thymus-DNA (CTDNA) were examined using the UV spectrophotometry. A CT-DNA solution was prepared by dissolving $2.5 \mathrm{mg}$ of CT-DNA in $10.0 \mathrm{~mL}$ of Tris- $\mathrm{HCl}$ buffer and it was used immediately after it was prepared. The concentration of CT-DNA was determined spectrophotometrically with the aid of $\varepsilon$ value of $6600 \mathrm{M}^{-1} \mathrm{~cm}^{-1}$ at $260 \mathrm{~nm}$. After dissolving the CT-DNA fibers in Tris-HCl buffer, the purity of this solution was checked through the absorbance ratio of A260/A280. The DNA was pure enough to use with respect to the result A260/A280 ratio of 1.83 obtained for the CTDNA solution in the buffer. These compounds dissolved in DMSO were re-diluted with Tris- $\mathrm{HCl}$ buffer to obtain the concentration of $25 \mu \mathrm{M}$. Test compounds in the solutions were incubated with CT-DNA solution at $20^{\circ} \mathrm{C}$ for about $30 \mathrm{~min}$ before measurements. The UV absorption spectra data were obtained without any change on the concentrations of both compounds with increasing the CT-DNA concentrations (0-100 $\mu \mathrm{M})$. Absorption spectra were recorded using 1-cm-path quartz cuvettes at room temperature [19]. 
To evaluate the interaction of the compounds with BSA, a UV spectrophotometer was used. A solution of BSA was prepared by dissolving $2.5 \mathrm{mg}$ BSA in $10.0 \mathrm{~mL}$ in Tris- $\mathrm{HCl}$ buffer and it was used immediately after it was prepared. The UV wavelength scans of the BSA solutions (0-100 $\mu \mathrm{M})$ with a fixed concentration of the complexes $(25 \mu \mathrm{M})$ were screened in the wavelength range of 250-320 nm.

The restriction on enzyme inhibition assay was conducted to determine the both specific and nonspecific binding and enzyme inhibition by the complexes. These complexes $(25 \mu \mathrm{M})$ were added to reaction tubes containing supercoiled PTOLT $(10 \mu \mathrm{M})$ plasmid DNA, and restriction enzymes $\mathrm{KpnI}$ and BamHI (2 units) in Tris- $\mathrm{HCl} / \mathrm{NaCl}$ buffer $(50 / 18 \mathrm{mM}, \mathrm{pH} 7.2$ ) and incubated at $37^{\circ} \mathrm{C}$ for $4 \mathrm{~h}$. The digestion products were observed by using $1.5 \%$ (wt/vol) agarose gel with ethidium bromide.

\section{Statistical analysis}

The statistical significance of differences was determined through one-way analysis of variance (one-way ANOVA) tests. Post hoc analyses of group differences were performed using the Tukey test, and the levels of probability were noted. The SPSS ${ }^{\circ}$ software for Windows was used for the statistical analyses. The results are reported as the mean values \pm SEM of three independent assays, and the differences between groups were regarded as significant at $P<0.05$.

\section{RESULTS and DISCUSSION}

\section{FT-IR Spectra}

In the FT-IR spectra of the $\boldsymbol{C 1 - C 6}$ compounds, absorption bands arising from all characteristic functional groups of the $\mathrm{N}$-bishydeten ligand ( $\mathrm{uOH}$ and $\mathrm{uNH}_{2}, \mathrm{uCH}_{2}, \delta \mathrm{NH}_{2}, \delta \mathrm{CH}_{2}, \mathrm{uC}-\mathrm{N}$ and uCO) vibrations were observed (Figure 1). Also, Figure 1 exhibits various characteristic absorption bands that confirm the presence of the $N, N$-bishydeten ligand, which coordinates to the metal centers via its $\mathrm{NH}_{2}$ and $\mathrm{OH}$ groups. The tentative assignments of the recorded wavenumbers of the C1-C6 compounds are in good agreement with the FT-IR spectra of the compounds synthesized and characterized in our previous studies [16-18]. 


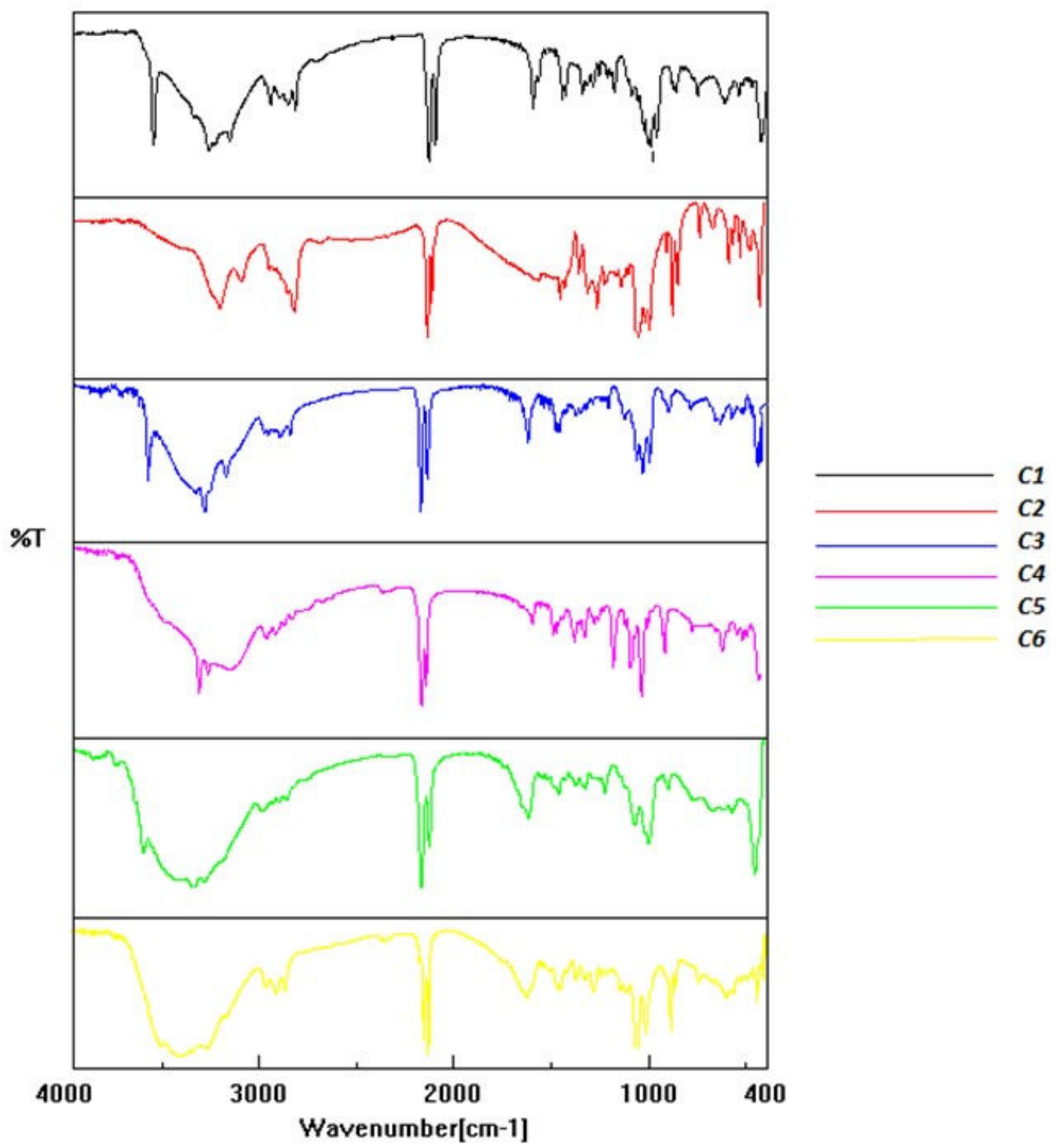

Figure 1. The FT-IR spectra of $\boldsymbol{C 1 - C 6}$ compounds.

\section{Anti-proliferative effects of the complexes against HT29, HeLa, C6 and Vero cells}

We firstly studied the in vitro anti-proliferative effects of six compounds using ELISA BrdU assay against three cancer cell lines (HT29, HeLa, and C6) and one non-cancerous cell line, namely Vero. The cis-platin, an anticancer drug, was used as a reference compound. The data obtained using the ELISA BrdU assay, \% inhibition data of the compounds was shown in Figure 2. IC50 values to be used in subsequent studies were calculated by XLfit 5 software and available in Table 1. Tumor specificity information was obtained by dividing the sum of the IC50 values obtained from the normal cells (Vero) to the sum of the IC50 values of the cancerous cells (HT29, HeLa, and (6) and given in Table 1. According to these information, the specificities of these compounds are not ideal because of poor selectivity. According to the Figure 1, in cis-platin case, each coordination polymer poorly inhibited the proliferation of cells as compared to the control compounds $(P<0.05)$. However, the compounds $\boldsymbol{C} 2$ and $\mathbf{C 6}$ have showed relatively strong antiproliferative activity to the cells while the compounds $\boldsymbol{C 1}$ and $\mathbf{C 4}$ have done slightly low. A gradient obtained from the percent inhibition values of these coordination polymers can be seen 
Aydın and Aslan Korkmaz, JOTCSA. 2016; 3(3): 313-328.

for complexes in order of activity starting with the highest in activity: $\mathbf{C 2}>\mathbf{C 6}>\mathbf{C 4}>\mathbf{C 1}>\mathbf{C 3}$ $\approx C 5$ (Fig. 2).

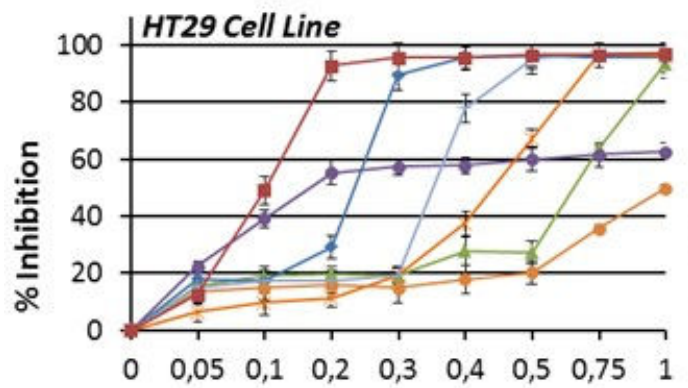

Concentration $(\mathrm{mg} / \mathrm{mL})$

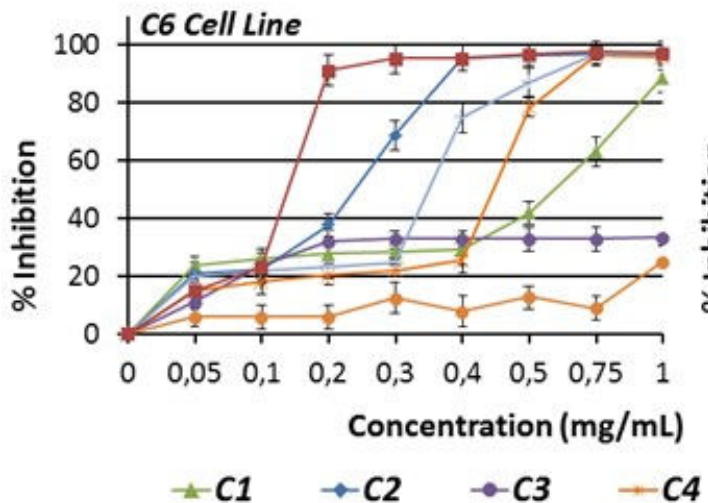

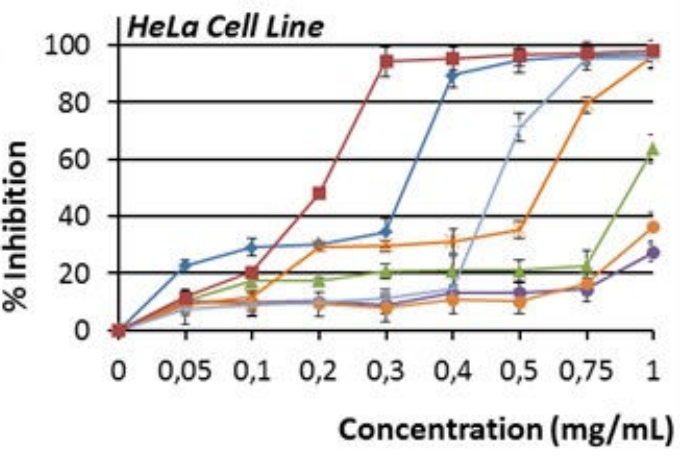

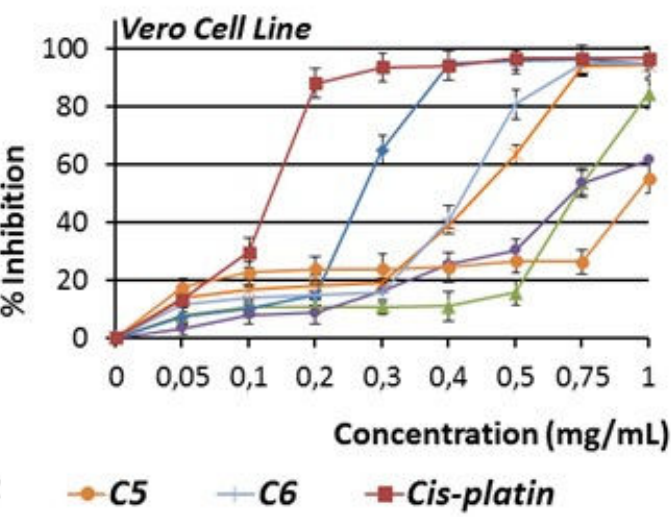

Figure 2. Effects of $\boldsymbol{C 1}$-C6 on the proliferation of cell lines. Percent inhibition was reported as mean values \pm SEM of three independent assays $(P<0.05)$.

The results of the cell proliferation assay have showed that the coordination compounds have less anti-proliferative effect than that of cis-platin (Fig. 2) on the cell lines indicating that their anticancer potential should be improved further.

Table 1. IC50 values for C1-C6 compounds and Cis-platin.

\begin{tabular}{lccccccc}
\hline & \multicolumn{4}{c}{ IC50 (mM) } & \multicolumn{4}{c}{ Tumor specificity } \\
Complex & HeLa & HT29 & C6 & Vero & HeLa & HT29 & C6 \\
\hline C1 & $-*$ & $1.60 \pm 0.04$ & $1.49 \pm 0.05$ & $2.11 \pm 0.07$ & - & 1.32 & 1.42 \\
C2 & $0.54 \pm 0.03$ & $0.46 \pm 0.02$ & $0.46 \pm 0.02$ & $0.58 \pm 0.03$ & 1.07 & 1.26 & 1.26 \\
C3 & - & $1.07 \pm 0.04$ & - & $1.87 \pm 0.06$ & - & 1.75 & - \\
C4 & $1.23 \pm 0.05$ & $1.11 \pm 0.04$ & $1.06 \pm 0.04$ & $1.11 \pm 0.05$ & 0.90 & 1.00 & 1.05 \\
C5 & - & - & - & - & - & - & - \\
C6 & $0.68 \pm 0.03$ & $0.52 \pm 0.03$ & $0.51 \pm 0.02$ & $0.62 \pm 0.03$ & 0.91 & 1,19 & 1.22 \\
Cisplatin & $0.80 \pm 0.03$ & $0.40 \pm 0.02$ & $0.57 \pm 0.03$ & $0.57 \pm 0.03$ & 0,71 & 1.43 & 1.00 \\
\hline
\end{tabular}

* not available.

\section{Cytotoxic activity of the complexes on HT29, HeLa, C6 and Vero cells}

The results obtained for the LDH assay are expressed in terms of percent cytotoxicity values and presented in Figure 3. Findings showed that the test compounds possess approximately percent nonselective toxicity values from $40 \%$ to $85 \%$ against the cells investigated. 


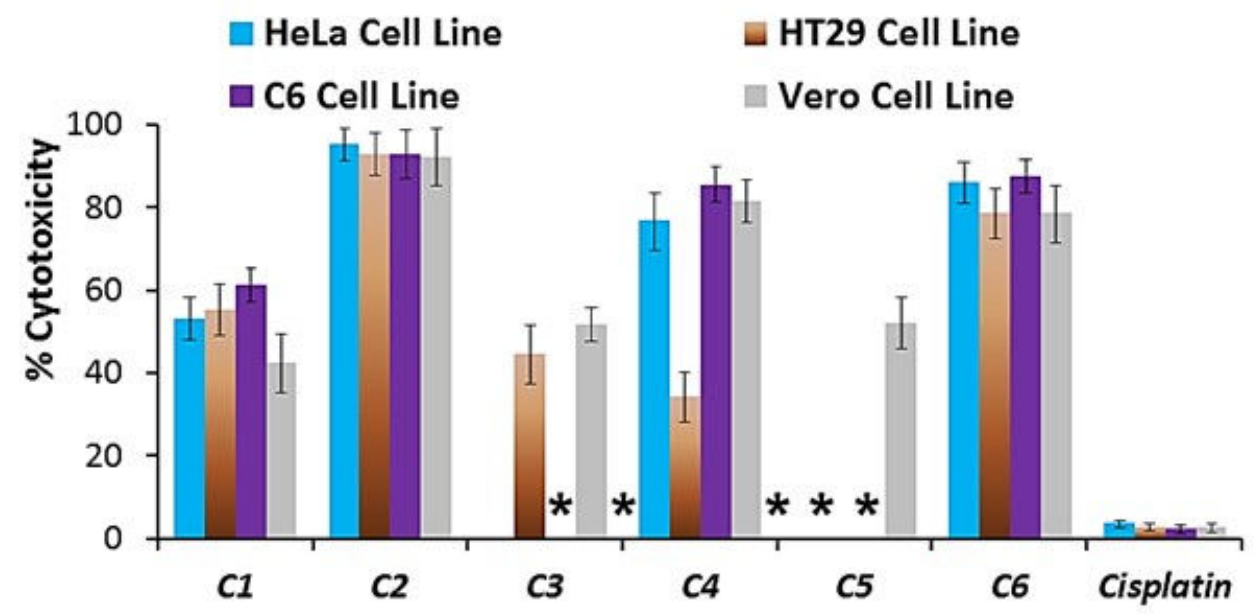

Figure 3. Cytotoxic activity of C1-C6 compounds on HeLa, HT29, C6 and Vero cells. Data are presented as the percent cytotoxicity of cells with respect to the control cells where only DMSO in cell culture media was administered. Cells were tested for $24 \mathrm{~h}$. The percent cytotoxicity values of test compounds were ranged from $40 \%$ to $85 \%$, and percent cytotoxicity value of cis-platin was approximately $5 \%$. The test compounds were the most cytotoxic $(P<0.05)$ against all cell lines tested. The percent cytotoxicity values were reported as mean values \pm SDs of three independent assays. * Not available.

According to another result, the cytotoxicity of each coordination polymer was significantly higher than that of cis-platin, at their IC50 concentrations against any of the four cell lines. This means that a safety usage concentration of the test compounds does not exist in the tested cells. It is suggested that these compounds may have cytostatic potential similar to cytotoxicity i.e., these coordination polymers are promising candidates for potential anticancer therapy for cancerous diseases. In our study, a variety of novel metal complexes were synthesized with the hopes of developing a useful drug candidate to use in cancer treatments.

\section{The effect of test compounds on the morphology of HT29, HeLa, C6 and Vero cells}

To determine the effect these complexes on the morphology of HeLa, HT29, C6 and Vero cells in culture, phase contrast pictures were taken for cell cultures analyzed. The pictures given above indicate that all the compounds tested possess considerable effects such as disruption of membrane integrity on the morphology of the cells. As shown in Figure 4, obvious morphological dose-dependent changes were observed in treated cells as compared to those of the untreated cells. The compounds clearly showed characteristic apoptotic changes in the surface morphology. 

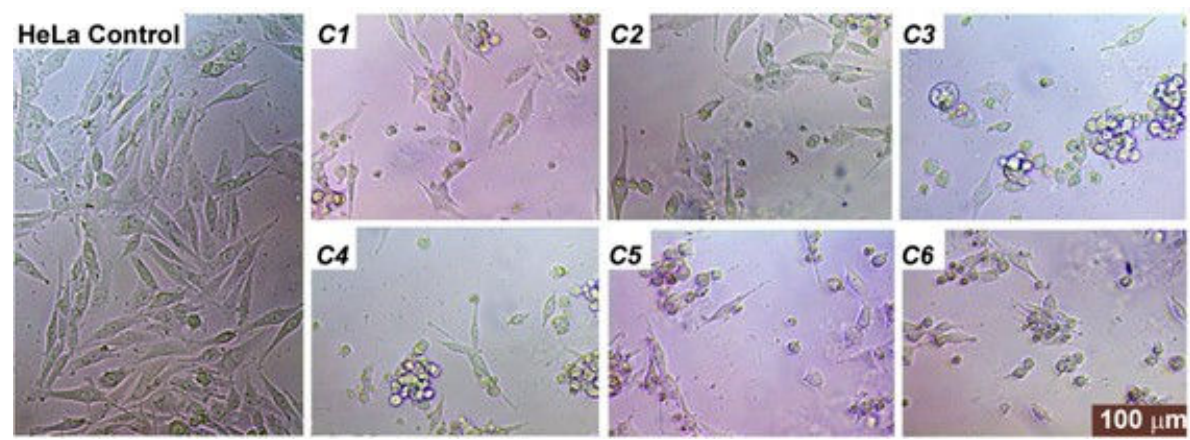

(A)
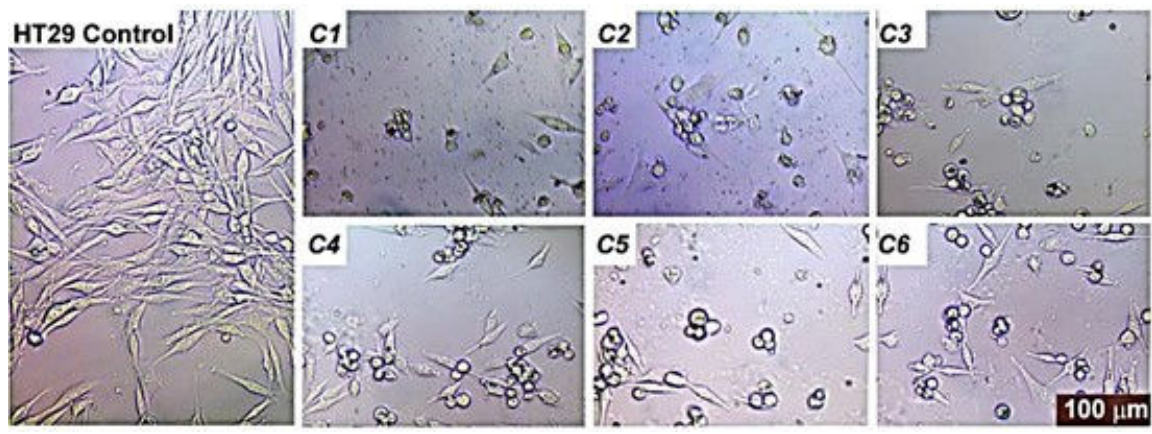

(B)

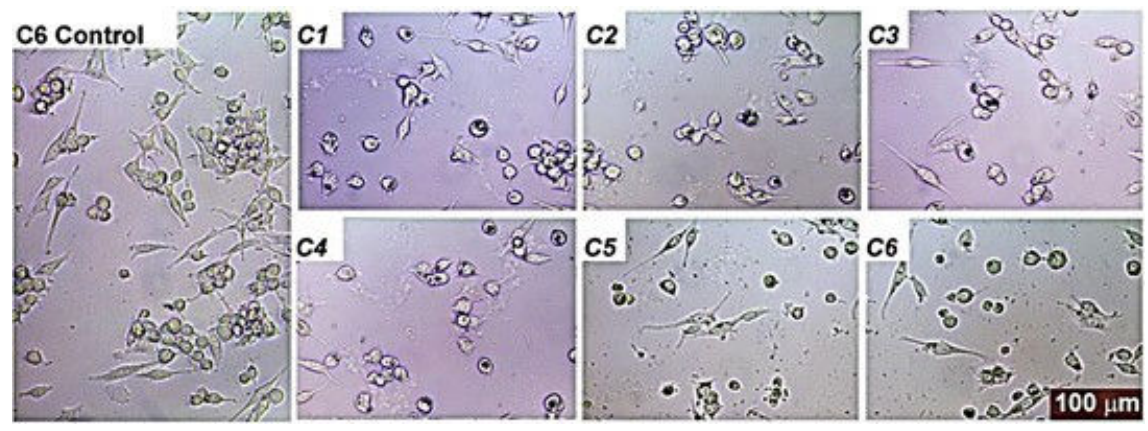

(C)
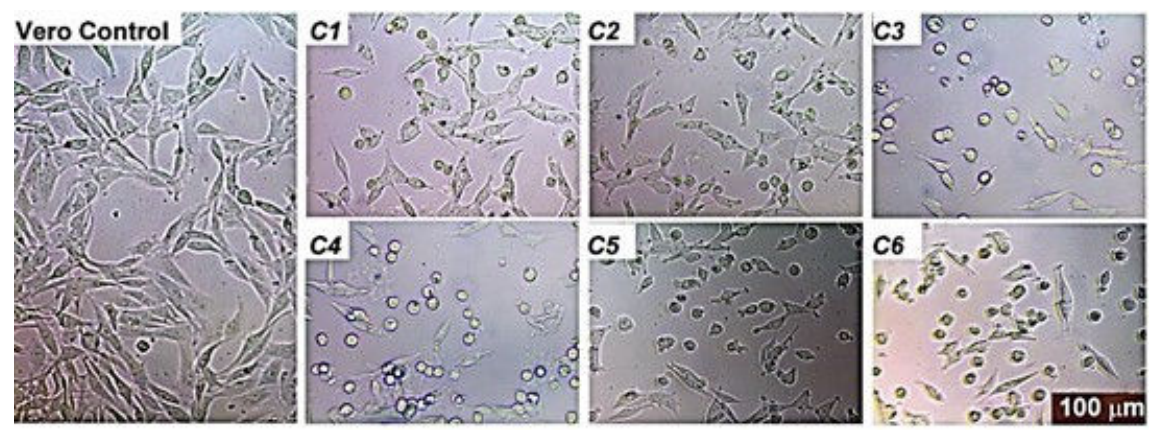

(D)

Figure 4. The effect of $\boldsymbol{C 1}$-C6 compounds on the morphology of HeLa (A), HT29 (B), C6 (C), and Vero $(\boldsymbol{D})$ cells. Exponentially growing cells were incubated with IC50 concentrations of test compounds at $37^{\circ} \mathrm{C}$ overnight and visualized by digital camera attached on an inverted microscope (Leica IL10, Germany).

These changes observed as rounding up, shrinking, and detaching from the well surface indicate that the cells were undergoing apoptosis which is a necessity for anticancer agents (Fig. 4) [20, 21]. The findings indicate that these morphological alterations are unlike necrotic situations 
Aydın and Aslan Korkmaz, JOTCSA. 2016; 3(3): 313-328.

which are usually characterized by cell swelling and eventual cell lysis. These results were somewhat similar with those of the previous studies by Korkmaz et al. [4], Aydın et al., [2, 6]. Thus, based on the observations in the literature, the appearance of cell lines treated with test compounds has indicated the anti-proliferative but high cytotoxic effect of these complexes clearly.

\section{DNA/BSA binding and gel electrophoresis studies}

Complex-DNA interactions can be investigated by comparing the UV-Vis absorption spectra of the free complex with that of complex-DNA adducts. The binding constant $(K)$ of the complexesDNA interaction can be determined according to Benesi-Hildebrand equation, $A_{0} / A-A_{0}=\varepsilon_{G} / \varepsilon_{H-G^{-}}$ $\varepsilon_{G}+\varepsilon_{G} / \varepsilon_{H-G}-\varepsilon_{G} \times 1 / K[D N A]$, where $K$ is the binding constant, $A_{0}$ and $A$ are the absorbance values of the complexes and their adducts with DNA, respectively, and $\varepsilon_{G}$ and $\varepsilon_{H-G}$ are the absorption coefficients of the complexes and the complex-DNA adducts, respectively. The binding constant can be obtained from the ratio of intercept to slope of $A_{0} /\left(A-A_{0}\right)$ vs. $1 /[D N A]$ plot. Figure $5 A$ describes the interaction of the complexes with CT-DNA. According to Benesi-Hildebrand equation, the data obtained from the plot of $A_{0} /\left(A-A_{0}\right)$ vs. 1/[DNA] yielded the binding constant (K) seen in Table 2. With the increase in CT-DNA concentration resulted in hyperchromic effect, a strong interaction between these complexes and DNA can be explained. This hyperchromic effect on the spectra of the complex-DNA adduct might be indication of the groove binding.

Table 2. The binding constants $\left(K_{b}\right)$

\begin{tabular}{cc}
\hline Complex & $U V$ titration $\left(\times 10^{3} \mathrm{M}^{-1}\right)$ \\
\hline C1 & 1.7 \\
C2 & 5.9 \\
C3 & 0.79 \\
C4 & 9.4 \\
C5 & 2.0 \\
C6 & 0.75 \\
\hline
\end{tabular}

The interaction of these complexes with BSA can be determined via comparison of UV-Visible absorption spectra of the free metal complex and the complex-BSA adduct. The absorption spectra of the BSA solutions (0-100 $\mu \mathrm{M})$ in the absence and presence of the complexes $(25 \mu \mathrm{M})$ are shown in Figure 5B. The complexes have caused an increase in the absorbance of BSA and exhibited a blue shift indicating the Van der Waals interaction or hydrogen bonds through interaction with BSA. Isosbestic points near 265 - $266 \mathrm{~nm}$ were observed for the C3, C5, and C6 compounds (Fig. 5B). 

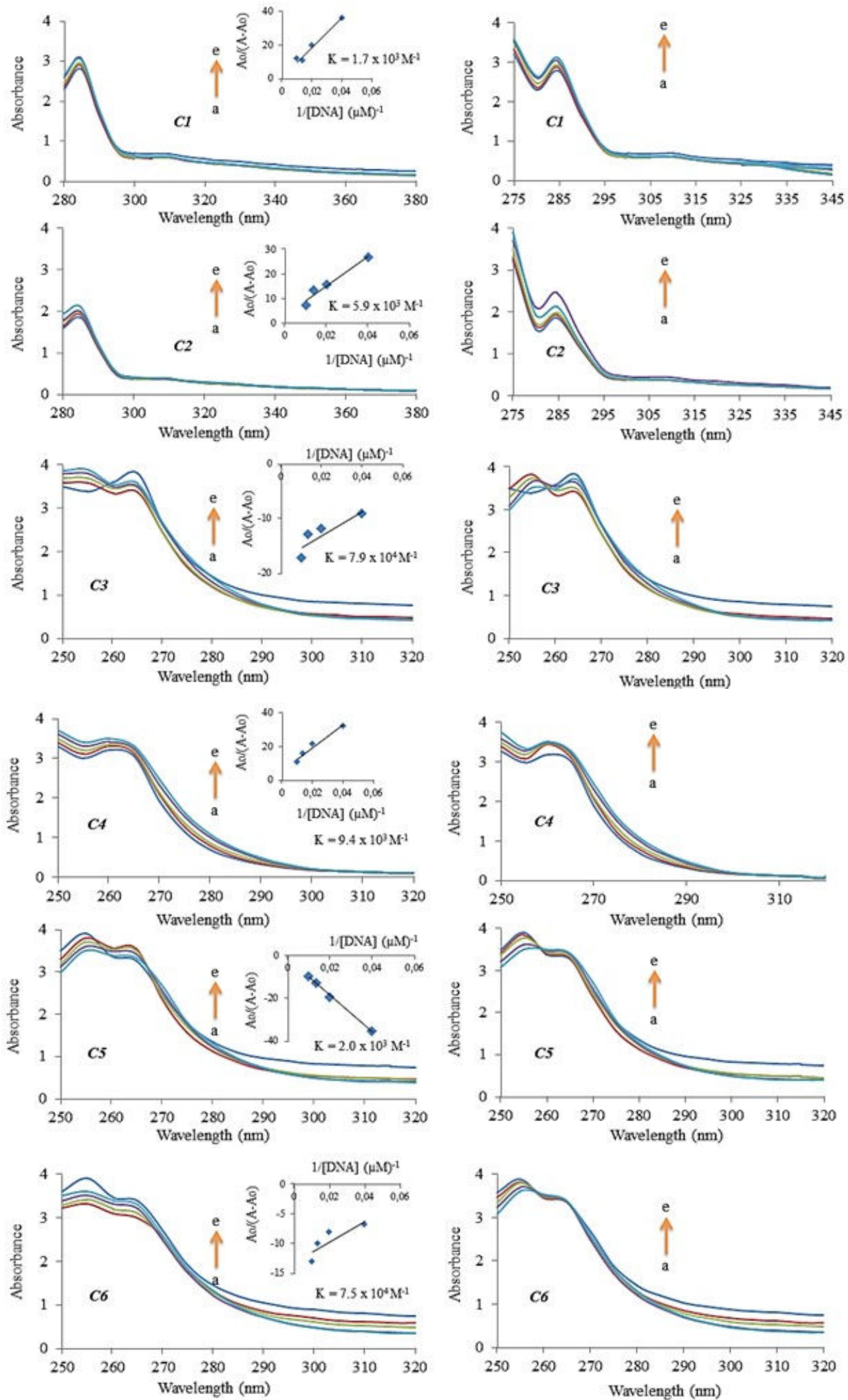

(A)

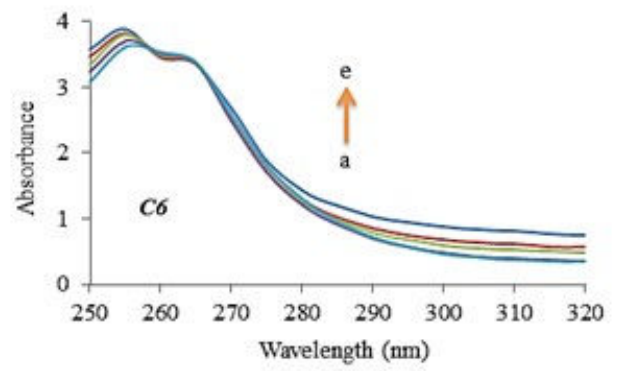

(B)

Figure 5. (A) UV-Visible absorption spectra of the complexes $(25 \mu \mathrm{M})$ in the absence (a) and presence $(b-e)$ of CT-DNA $(0-100 \mu \mathrm{M})$ in Tris-HCl buffer. Note: The direction of arrow demonstrates the increasing concentrations of DNA. Inset is the plot of $A_{0} /\left(A-A_{0}\right)$ vs. $1 /[D N A]$ to find the binding constant of the complex - DNA adduct. (B) Absorption spectra of the complexes $(25 \mu \mathrm{M})$ in the absence (a) and presence (b-e) of BSA $(0-100 \mu \mathrm{M})$ in Tris- $\mathrm{HCl}$ buffer. Note: The direction of arrow demonstrates the increasing concentrations of BSA. 
Aydın and Aslan Korkmaz, JOTCSA. 2016; 3(3): 313-328.

After KpnI and BamHI digestion of pTOLT plasmid DNA (patented plasmid vector, US 7348408 B2), digestion products were identified by two DNA bands in the absence of the complexes (Lane 7), whereas in the presence of the $\boldsymbol{C 1}, \boldsymbol{C} 3$ and $\mathbf{C 5}$ compounds have produced three bands (Lanes 2, 4, and 6) and the $\boldsymbol{C 2}, \boldsymbol{C 4}$ and $\boldsymbol{C 6}$ compounds have displayed four bands of DNA fragments seen near the well at the top of the lanes (Lanes 1, 3, and 5) (Fig. 6). In the presence of the complexes, DNA digestion was incomplete and new bands were observed. Treatment of KpnI and BamHI with the complexes inhibits partly the restriction endonucleases activity of these enzymes, and therefore more bands were seen on the gel. The results indicated that the complexes probably bound to PTOLT plasmid DNA or to these enzymes, and thus this situation has resulted in inhibition of $K p n I$ and BamHI enzyme activity to a certain degree.

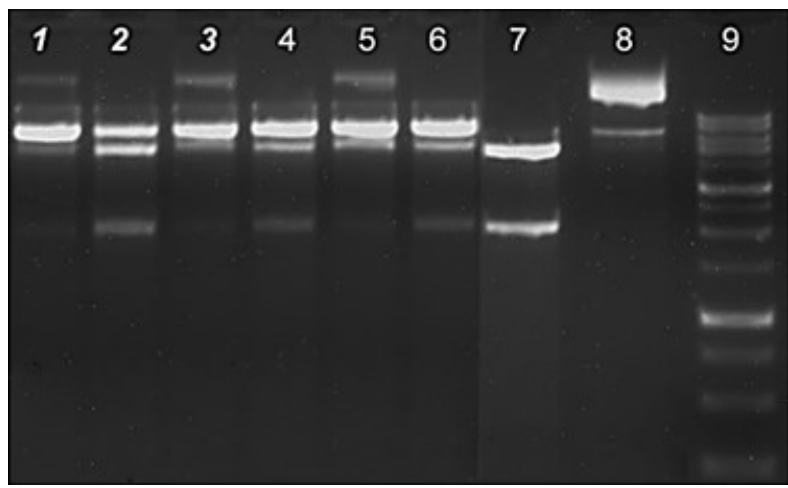

Figure 6. Inhibition of $K p n I$ and BamHI restriction endonucleases activity. At the end of $4 \mathrm{~h}$ at $37^{\circ} \mathrm{C}$ digestion of the $14 \mu \mathrm{L}$ with $10 \mathrm{U} \mathrm{KpnI}$ and $\mathrm{BamHI}$, these digestion products were resolved with $1.5 \%$ agarose gel containing ethidium bromide. Lanes 1-6: enzyme + DNA + C1-C6, Lane 7: Positive control (enzyme + DNA), Lane 8: Negative control (plasmid DNA + water);

lane 9: DNA marker (1Kb).

The goal of this study is to find new metal complexes active in vivo and possess lowered toxicity and resistance factors as compared to current chemotherapeutic drugs. In conclusion, in vitro anticancer activity of $\left[\mathrm{Ni}(\mathrm{N}\right.$-bishydeten $\left.) \mathrm{Ni}(\mathrm{CN})_{4}\right](\boldsymbol{C 1}),\left[\mathrm{Zn}_{2}(\mathrm{~N} \text {-bishydeten })_{2} \mathrm{Ni}(\mathrm{CN})_{4}\right](\mathrm{C2}),[\mathrm{Ni}(\mathrm{N}$ bishydeten $\left.) \mathrm{Pd}(\mathrm{CN})_{4}\right] \quad(\mathbf{C 3}), \quad\left[\mathrm{Cd}(\mathrm{N} \text {-bishydeten })_{2}\right]\left[\mathrm{Pd}(\mathrm{CN})_{4}\right] \quad(\mathrm{C4}), \quad\left[\mathrm{Ni}_{2}(\mathrm{~N}\right.$ bishydeten $\left.)_{2} \mathrm{Co}(\mathrm{CN})_{6}\right] .3 \mathrm{H}_{2} \mathrm{O}(\mathrm{C5})$ and $\mathrm{K}\left[\mathrm{Cd}(\mathrm{N}\right.$-bishydeten $\left.) \mathrm{Co}(\mathrm{CN})_{6}\right] .1 .5 \mathrm{H}_{2} \mathrm{O}(\mathbf{C 6})$ coordination compounds were investigated and determined. The binding of the complexes to CT-DNA and BSA resulted in significant changes in spectral characteristics. The complexes have showed hyperchromic absorption spectra and interacted directly with CT-DNA through a groove binding mode. The complexes have the tendency to possess Van der Waals contacts or hydrogen bonds during interaction with BSA. The complexes caused partial inhibition of KpnI and BamHI restriction endonucleases activity indicating that the complexes could interact with CT-DNA or these enzymes or both. On the contrary, C5 and $\mathbf{C 3}$ compounds were nearly ineffective against all four cell lines. All remaining metal complexes have showed impressive anticancer activity against all cancer cells tested. However, in a preliminary in vitro study, these metal complexes appear to be nonselective against HT29, HeLa, C6 and Vero cells. These preliminary results are important because they indicate that these complexes have affected normal Vero cells. For these reasons, we believe that these complexes need to be developed by making a more rational 
Aydın and Aslan Korkmaz, JOTCSA. 2016; 3(3): 313-328.

RESEARCH ARTICLE

design. Therefore, they may be a future replacement to the chemotherapeutic drugs in the clinical usage. As a conclusion, it seems substantial to continue to improve these chemical complex compounds to further help the problem of cancer.

\section{ACKNOWLEDGMENTS}

The authors thank to the Tunceli University Research Foundation (Grant MFTUB014-05) for financial support.

\section{AUTHOR CONTRIBUTIONS}

AA and SAK designed and performed experiments, analyzed the data, and wrote the paper.

\section{REFERENCES}

1. World Cancer Report 2014. http://www.iarc.fr/en/publications/books/wcr/wcr-order.php (accessed 16.04.16).

2. Aydın A, Korkmaz N, Tekin Ş, Karadağ A. Anticancer activities and mechanism of action of 2 novel metal complexes, $\mathrm{C}_{16} \mathrm{H}_{34} \mathrm{~N}_{8} \mathrm{O}_{5} \mathrm{Ag}_{2} \mathrm{Cd}$ and $\mathrm{C}_{11} \mathrm{H}_{16} \mathrm{~N}_{7} \mathrm{O}_{2} \mathrm{Ag}_{3} \mathrm{Ni}$. Turk J. Biol. 2014; 38,948-955. http://doi.org/10.3906/biy-1405-68.

3. Karadağ A, Aydın A, Özdemir A, Tekin Ş. Anti-proliferative and cytotoxic activities of a new cyanido coordination compound on several cancer cell lines. J. Biotechnol. 2014; 185, 105. http://doi.org/10.1016/j.jbiotec.2014.07.358.

4. Korkmaz N, Karadağ A, Aydın A, Yanar Y, Karaman İ, Tekin Ş. Synthesis and characterization of two novel dicyanidoargentate(I) complexes containing $\mathrm{N}$-(2-hydroxyethyl)ethylenediamine exhibiting significant biological activity. New J. Chem. 2014; 38, 4760-4773. http://doi.org/10.1039/C4NJ00851K.

5. Tekin S, Aydın A, Dede S, Karadağ A. Anti-proliferative activity of a new coordination compound containing AuI(CN)2 in some cancer cell lines. J. Biotechnol. 2014; 185, 28-29. http://doi.org/10.1016/j.jbiotec.2014.07.096.

6. Aydın A, Karadağ A, Tekin Ş, Korkmaz N, Özdemir A. Two new coordination polymers containing dicyanidoargentate(I) and dicyanidoaurate(I): synthesis and characterization, and a detailed in vitro investigation of their anticancer activities on some cancer cell lines. Turk J. Chem. 2015; 39, 532-549. http://doi.org/10.3906/kim-1412-13.

7. Karadağ A, Aydın A, Dede S, Tekin Ş, Yanar Y, Çadırcı BH, Soylu MS, Andaç Ö. Five Novel Dicyanidoaurate(I)-Based Complexes Exhibiting Significant Biological activities: Synthesis, Characterization and Three Crystal Structures. New J. Chem. 2015; 39, 8136-8152. http://doi.org/10.1039/C5NJ01108F. 
Aydın and Aslan Korkmaz, JOTCSA. 2016; 3(3): 313-328.

8. Dabrowiak JC. Metals in Medicine. John Wiley \& Sons, 2009. 1st Edition, 321 p, West Sussex, UK. ISBN: $978-0-470-68196-1$.

9. Osowole AA, Akpan EJ. Synthesis, Spectroscopic Characterisation, In-Vitro Anticancer and Antimicrobial Activities of Some Metal(II) Complexes of 3-\{4, 6-Dimethoxy Pyrimidinyl) Iminomethyl Naphthalen-2-ol. European Journal of Applied Sciences 2012; 4(1), 14-20.

10. Abd-Elzaher MM, Labib AA, Mousa HA, Moustafa SA, Ali MM, El-Rashedy AA. Synthesis, anticancer activity and molecular docking study of Schiff base complexes containing thiazole moiety. BeniSuef Univ. J. Basic Appl. Sci. 2016; 5(1), 85-96. DOI: 10.1016/j.bjbas.2016.01.001.

11. Tan KW, Seng HL, Lim FS, Cheah SC, Ng CH, Koo KS, Mustafa MR, Ng SW, Maah MJ. Towards a selective cytotoxic agent for prostate cancer: Interaction of zinc complexes of polyhydroxybenzaldehyde thiosemicarbazones with topoisomerase I. Polyhedron 2012 ; 38, 275284. DOI: 10.1016/j.poly.2012.03.014.

12. Kapdi AR, Fairlamb IJS. Anti-cancer palladium complexes: a focus on $P d X_{2} L_{2}$, palladacycles and related complexes. Chem. Soc. Rev. 2014; 43, 4751. http://dx.doi.org/10.1039/c4cs00063c.

13. Angelè-Martìnez C, Goodman C, Brumaghim J. Metal-mediated DNA damage and cell death: mechanisms, detection methods, and cellular consequences. Metallomics 2014; 6, 1358. http://doi.org/10.1039/c4mt00057a.

14. Vignesh G, Senthilkumar R, Paul P, Periasamy VS, Akbarsha MA, Arunachalam S. Protein binding and biological evaluation of a polymer-anchored cobalt(III) complex containing a 2,20-bipyridine ligand. RSC Adv. 2014; 4, 57483. http://doi.org/10.1039/c4ra10377g.

15. Pages BJ, Ang DL, Wright EP, Aldrich-Wright JR. Metal complex interactions with DNA. Dalton Trans. 2015; 44, 3505. http://dx.doi.org/10.1039/c4dt02700k.

16. Karadağ A, Aslan Korkmaz Ş, Andaç Ö, Yerli Y, Topcu Y. Cyano-complexes and salts with tetracyanonickellate ${ }^{\mathrm{II}}$ and $\mathrm{N}, \mathrm{N}$-bis(2-hydroxyethyl)-ethylenediamine: synthesis, IR spectra, magnetic properties, thermal analyses, and crystal structures. Journal of Coordination Chemistry. 2012; 65, 10, 1685-1699. http://dx.doi.org/10.1080/00958972.2012.678337.

17. Aslan Korkmaz Ş, Karadağ A, Korkmaz N, Andaç Ö, Gürbüz N, Özdemir İ, Topkaya R. Five complexes containing N,N-bis(2-hydroxyethyl)-ethylenediamine with tetracyanidopalladate(II): synthesis, crystal structures, thermal, magnetic, and catalytic properties. Journal of Coordination Chemistry. 2013; 66, 17, 3072-3091. http://dx.doi.org/10.1080/00958972.2013.820827.

18. Aslan Korkmaz Ş, Karadağ A, Yerli Y, Soylu MS. Synthesis and characterization of new heterometallic cyanido complexes based on $\left[\mathrm{Co}(\mathrm{CN})_{6}\right]^{3-}$ building blocks: crystal structure of $\left[\mathrm{Cu}_{2}(\mathrm{~N}-\right.$ bishydeten $\left.)_{2} \mathrm{Co}(\mathrm{CN})_{6}\right] .3 \mathrm{H}_{2} \mathrm{O}$ having a strong antiferromagnetic exchange. New J. Chem. 2014; 38, 5402-5410. http://dx.doi.org/10.1039/c4nj00737a.

19. Sirajuddin M, Ali S, Badshah A. Drug-DNA interactions and their study by UV-Visible, fluorescence spectroscopies and cyclic voltammetry. J. Photochem. Photobiol. B 2013; 124, 1-19. http://dx.doi.org/10.1016/j.jphotobiol.2013.03.013.

20. Dabrowiak JC. Metals in Medicine. John Wiley \& Sons, 2009. 1st Edition, 321 p, West Sussex, UK. ISBN: 0-470-68196-1.

21. Gielen M, Tiekink ERT. Metallotherapeutic Drugs and Metal-Based Diagnostic Agents: The Use of Metals in Medicine. John Wiley \& Sons press, 2005. 644 p, West Sussex, UK. ISBN: 0-470-864036. 


\title{
Altı Koordinasyon Bileşiği: Sitotoksik Etki Modu ve Biyolojik Değerlendirme
}

\author{
Ali Aydın, Şengül Aslan Korkmaz
}

\begin{abstract}
Öz: Bu çalışma metinde verilmiş koordinasyon bileşiklerinin biyolojik ve antikanser özelliklerini anlatmaktadır. Altı adet siyanido kompleks türevinin FT-IR spektrumları, manyetik özellikleri, termal analizler ve kristal yapıları verilmiştir, burada $\left[\mathrm{M}^{\mathrm{II}}(\mathrm{CN})_{4}\right]^{2-}\left(\mathrm{M}^{\mathrm{II}}=\mathrm{Ni}\right.$ ve $\left.\mathrm{Pd}\right)$ ve $\left[\mathrm{Co}(\mathrm{CN})_{6}\right]^{3-}$ olup "şapka" ligand olarak $N, N$-bishydeten ( $N, N$-bis(2-hidroksietil)etilendiamin) olarak daha önce çalışılmıştır. Bu çalışmada, söz konusu komplekslerin (C1-C6) farmakolojik özellikleri incelenmiş ve insan rahim ağzı kanseri (HeLa), insan kalınbağırsak kanseri (HT29), sıçan glioma (C6) ve Afrika yeşil maymun böbrek (Vero) hücre soylarına karşı anti-proliferatif aktiviteleri incelenmiştir. C1-C6 komplekslerinin açlımı şöyledir: [Ni(N-bishydeten $\left.) \mathrm{Ni}(\mathrm{CN})_{4}\right](\mathbf{C 1}),\left[\mathrm{Zn}_{2}(\mathrm{~N}-\right.$ bishydeten $\left.)_{2} \mathrm{Ni}(\mathrm{CN})_{4}\right]$ (C2), [Ni( $\mathrm{N}$-bishydeten $\left.) \mathrm{Pd}(\mathrm{CN})_{4}\right](\mathbf{C 3}), \quad\left[\mathrm{Cd}(\mathrm{N} \text {-bishydeten })_{2}\right]\left[\mathrm{Pd}(\mathrm{CN})_{4}\right]$ (C4), $\left[\mathrm{Ni}_{2}(\mathrm{~N} \text {-bishydeten })_{2} \mathrm{Co}(\mathrm{CN})_{6}\right] \cdot 3 \mathrm{H}_{2} \mathrm{O}(\mathrm{C5})$ and $\mathrm{K}\left[\mathrm{Cd}\left(\mathrm{N}\right.\right.$-bishydeten) $\left.\mathrm{Co}(\mathrm{CN})_{6}\right] . \mathrm{H}_{2} \mathrm{O}(\mathbf{C 6})$. Bu bileşiklerin DNA/BSA bağlanma istekleri de spektroskopik titrasyonlar, yer değiştirme deneyleri ve elektroforez ölçümleri ile ortaya konmuştur. Kanserli hücreler üzerindeki çalışmalar C1, C2, C4 ve $\mathbf{C 6}$ bileşiklerinin belirgin antitümör aktivitesini göstermiş ve test edilen hücre soylarında tümör gelişimini azaltmıştır. Bu bileşiklerin çözücü içindeki çözünürlüğü de son derece yüksektir. Absorbans ve emisyon spektrum sonuçları, komplekslerin DNA ile groove-bağlanma etkileşimi gösterdiğini ortaya çıkarmıştır. Bütün bunların sonucunda, söz konusu bileşiklerin kanser hücre soylarına karşı etkili anti-proliferatif aktivite gösterdiği bulunmuştur, dolayısı ile pre-klinik veya klinik çalışmalar için potansiyel adaylar olarak gösterilebilir.
\end{abstract}

Anahtar Kelimeler: Koordinasyon bileşikleri, Antikanser aktivitesi, Sitotoksik aktivite, Apoptoz, DNA bağlanması.

Gönderme: 26 Haziran 2016. Düzeltme: 06 Ağustos 2016. Kabul: 06 Eylül 2016. 